\title{
Sofiya Likhova
}

National Aviation University in Kyiv, Ukraine

ORCID: 0000-0003-4755-7474

k_kpipp@ukr.net

\section{Marek Mozgawa}

Maria Curie-Skłodowska University in Lublin, Poland

ORCID: 0000-0002-7341-6563

marek.mozgawa@umcs.pl

\section{Criminal Law Protection of the Autonomy of Patients in Ukraine: Analysis of Possible Grounds for Criminal Liability. Part 2}

\author{
Prawnokarna ochrona autonomii pacjenta na Ukrainie - analiza \\ możliwych podstaw odpowiedzialności karnej. Część druga
}

\begin{abstract}
The aim of the article is to analyze the phenomenon of "patient's autonomy" as an object of criminal law protection. The article is divided into two parts. In this part, attention is focused on discussing possible grounds for criminal liability in case of violation of patient's autonomy. It should be stressed that, of course, only some of the behaviors violating the legal good of patient's autonomy is regulated by criminal law and may therefore result in criminal liability. The authors analyze offences whose commission by medical personnel may violate patient's autonomy. In addition, they present statistics on the number of medical crimes for 2019.
\end{abstract}

Keywords: patient's autonomy; criminal liability; offences; medical personnel; criminal law protection

CORRESPONDENCE ADDRESS: Sofiya Likhova, PhD, Professor, Faculty of Law, National Aviation University (Kyiv), 1, Liubomyra Huzara ave. 03058, Ukraine; Marek Mozgawa, PhD, Prof. Dr. Habil., Full Professor, Maria Curie-Skłodowska University (Lublin), Faculty of Law and Administration, Institute of Law, Plac Marii Curie-Skłodowskiej 5, 20-031 Lublin, Poland. 


\section{INTRODUCTION}

It should be noted that the principle of patient's autonomy can and is violated by the state, government bodies, local authorities and other legal persons. The social harmfulness of such violations of law is much more serious than the crimes whose characteristics are defined in the Criminal Code of Ukraine (hereinafter: CCU). In view of the framework and purpose of this article which is the second part of the study, ${ }^{1}$ we analyze these statutory constitutive features of crimes that are committed by natural persons - medical and pharmaceutical workers. Each of these crimes has a significant impact on patient's autonomy. The legal protection of patient's autonomy is achieved by criminalising individual behaviours as a result of which the patients' rights are infringed by certain actors. By establishing criminal liability for such acts, the State implements a mechanism for the criminal-law protection of certain legal relationships from socially dangerous violations, and in this particular case, in the field of safeguarding the implementation of the fundamental principle of bioethics, namely the principle of patient's autonomy.

In the study, the authors used the method of legal text analysis and the analysis of statistical data showing the scale of the phenomenon of medical offences in practice.

\section{ANALYSIS OF OFFENCES AGAINST PATIENT'S AUTONOMY}

Before starting the dogmatic analysis, we would like to point out that the number of offences committed by medical or pharmaceutical professionals in connection with the performance of their professional duties is significant. Statistics provided by the Office of the Attorney General indicate that their number has increased in recent years (937 such offences were recorded between 2003 and 2012, 714 in 2013, 620 in 2014, 676 in 2015, 768 in 2016, 792 in 2018, 868 in 2019). ${ }^{2}$ Scholars emphasise the existence of circumstances that artificially increase the so-called dark number of these offences. These factors include the distortion of statistical reporting and the imperfect construction of criminal law provisions, and consequently errors in the legal qualification of certain types of behavior, which in turn makes it impossible to prove the guilt of the perpetrator. ${ }^{3}$

1 See S. Likhova, M. Mozgawa, Criminal Law Protection of the Autonomy of Patients in Ukraine. Part 1, "Studia Iuridica Lublinensia" 2021, vol. 30(4), pp. 373-391.

2 Office of the Attorney General, www.gp.gov.ua/ua/1stat [access: 20.09.2021].

3 Y.O. Shopina, Kryminalna vidpovidalnist medychnoho abo farmatsevtychnoho pratsivnyka za vchynennya zlochynu, povyazanoho z vykonannyam profesiynykh obovyazkiv, Kyyiv 2020 (dysertatsiya kandydata yurydychnykh nauk), p. 15. 
Article $137 \mathrm{CCU}$ ("Improper exercise of duties to protect the life and health of children") defines the liability for the failure to perform or improper performance of professional or official duties to protect the life and health of minors due to negligence or undue treatment. The criminal liability for such conduct shall only take place where there are certain consequences which are directly set out in the provision, namely significant damage to the health of the injured. Significant damage is defined as a set of factors that were not expected by the person concerned, but nonetheless should have and could have been expected. The aggravated type of this offence covers particularly serious consequences such as the death of a minor as well as other serious consequences. An analysis of the construction of the offence characteristics set out in paras. 1 and 2 of Article 137 CCU leads to the conclusion that this is an unintentional offence. It should be noted that the provisions of these two paragraphs do not specify the features of the offender. However, its analysis allows us to conclude that in some cases such actors may also include medical staff. This occurs, for example, in the case of failure to provide medical, psychological and other assistance free of charge, or where free prosthetics are not provided to disabled children, or where necessary assistance is not provided to children with AIDS or other incurable diseases.

Article 138 CCU ("Illegal medical activities") provides for liability for the performance of medical activities without licence by a person without appropriate medical education. A necessary statutory feature of this offence is the serious consequences - causing death, serious damage to the health of one person or moderate damage to the health of two or more people.

The analysis of offences committed in the medical sphere shows a serious problem which needs to be addressed. It concerns the concept of an injured party. In the statutory features of the offence under Article $138 \mathrm{CCU}$ the injured party is referred to as "the ill person". Most regulations also use this term (Articles 139 and $140 \mathrm{CCU}$ ). Article $140 \mathrm{CCU}$ provides for the liability for infringement of patient's rights, while Article $142 \mathrm{CCU}$ provides for the liability for illegal experiments on human beings. In comments on these articles and in scientific literature, the terms "ill person", "human beings" (in the context of criminal law norms) or "patient" are often used as synonyms. Considering patient's autonomy, this entails the question of whether the word "patient" is to be understood in its narrow sense or rather a broad approach should be adopted? If the notion of patient is understood only as a person who is ill and has sought medical care, then the principle of autonomy will not apply to people who are not ill but have requested medical assistance (for example, for the services of a plastic surgeon, for aesthetic dentistry services and prosthetics). Such people should also act in accordance with the principle of autonomy: choose a doctor, demand high quality medical services and fully exercise their rights. Thus, we believe that the term "patient" in the context of patient's autonomy should be understood as any person who is a party to the doctor-patient legal relationship. 
This means that the word "patient" must be understood broadly in this context. For example, a person who is not ill may choose a doctor to provide primary health care, and a completely healthy person may also apply for a health certificate. All these people have the right to patient's autonomy.

Getting back to the analysis of the statutory features of the offence of "illegal medical activity", it should be noted that it may be committed both by a person who does not have any medical training and a person with medical training, but who conducts a medical activity outside the scope of his specialisation or degree of professional training. This means that these offences can only partially be referred to as prohibited acts committed in the medical sphere. There are also people providing services of traditional medicine, i.e. so-called healers. In accordance with Ukraine's health legislation, the possession of medical profession licences by doctors is confirmed by appropriate documents. In the field of traditional medicine services, the qualification requirements for individual entrepreneurs are set by the Ministry of Health, and special permits are issued (and revoked) by the Cabinet of Ministers of Ukraine.

Of course, the patient can seek assistance of any doctor, according to the principle of autonomy. However, from the point of view of the classification of offences, it must be defined who is not the offender of "illegal medical activity", e.g., a nurse who performs the prescribed procedure for a fee to the patient, or an ophthalmologist who examines the patient for a fee and recommends glasses to him. If these services are provided in a state or municipal healthcare establishment, only the unlawfulness of the payment request shall be punishable under criminal law, provided that those services are not on the list of paid services. Such acts can be classified as an infringement of the right to free medical care (para. 1 of Article $184 \mathrm{CCU}$ ).

If a person with appropriate medical training conducts therapeutic sessions intended for a mass audience or otherwise, using hypnosis or other methods of mental or bioenergy influence, this behaviour (with other statutory features of the offence fulfilled) may be classified as illegal experiments on human beings (in terms of experimental methods) (Article $142 \mathrm{CCU}$ ).

In line with the principle of patient's autonomy, the patient can at his/her own discretion choose a doctor, a health care professional, and a medical institution. If the patient seeks medical advice from a person who does not have medical training at all, then such a situation does not generate a doctor-patient relationship. Relationships are created that are not covered by the regulation of medical law. If such relations result in a detriment to the health or life of a person, such actions, combined with other statutory features, should be considered as offences against life and health. This situation develops outside the implementation of the principle of patient's autonomy.

One of the elements of the principle of patient's autonomy, which is directly expressed in the patient's right to be provided a timely and skillful medical care, is the primary and overriding duty of the doctor to provide such assistance to a person 
who needs it. The criminal liability for non-compliance with this obligation is laid down in Article $139 \mathrm{CCU}$ ("Failure to provide aid to the patient by a healthcare professional"). This provision directly specifies both the injured party and the offender.

In this case, an injured party is an ill person - an individual who has been seriously injured or is in another acute medical condition. From the point of view of interpretation of this norm, we are not talking about any ill person, but about a person who is in a condition requiring urgent medical care. The regulations in force define health care as the activity of professionally trained medical staff aimed at prevention, diagnosis, treatment and rehabilitation in connection with diseases, injuries, poisoning and pathological conditions, as well as in connection with pregnancy and childbirth. There are such types of medical care as: emergency, primary, secondary (specialist), tertiary (highly specialized), palliative and medical rehabilitation.

This norm determines the criminal liability for failure to provide immediate medical assistance (without due reason). It is about a person who is in a condition requiring immediate action. It is a sudden deterioration in physical or mental health that poses an immediate and imminent threat to life and health and is the result of both disease and other internal and external factors. In this case, the injured party does not necessarily have to be a patient or an ill person. It may be a completely healthy person who has been affected by, for example, a traffic accident. In such cases, the intervention of a rescue team is necessary.

Failure to provide assistance to the ill person (within the meaning of Article 139 $\mathrm{CCU}$ ) should be understood as the doctor's refusal to accept the notification, doctor's failure to appear once notified, refusal to admit the patient to a health care facility for the purpose of first aid in the event of an accident, interruption of behaviour aimed at maintaining the life of the patient when his death has not yet been confirmed.

The criminal liability for this offence takes place when a medical staff member had an actual possibility of providing medical assistance. Therefore, it will not take place, for example, when during the transport of the ill person (injured party) by the rescue team there were sudden complications that require special hospital conditions, which cannot be objectively ensured. In this case, the medical staff of the emergency medical service, acting in accordance with the provisions of the Act on Emergency Medical Assistance, ${ }^{4}$ are not criminally liable even in the event of the death of a person. But if a medical institution refuses to admit such an injured party or does not provide assistance on time, the relevant employees of such a medical facility are liable.

The legislature provides for, as an obligatory feature of the actus reus of the offence, that the condition for an offence to be committed is the lack of significant reasons for not providing the necessary help. The occurrence of these significant

4 Zakon Ukrayiny of 5 July 2012, no. 5081-VI, Pro ekstrenu medychnu dopomohu, https:// zakon.rada.gov.ua/laws/show/5081-17\#Text [access: 20.09.2021]. 
reasons relieves the medical professional of liability. Significant reasons should be understood as force majeure (natural disaster, weather conditions), case of necessity, the lack of a doctor with special qualifications, the inability to call such a doctor in a timely manner, an elementary lack of necessary medicines and preparations in the medical facility, which, unfortunately, is not uncommon in today's Ukraine.

Ambiguous situations occur when, in urgent cases, the patient or his relatives refuse taking the necessary action. For example, it is necessary to undergo amputation or remove the damaged organ to save the life of the injured. In such cases, the doctor must take responsibility himself/herself as a person having adequate knowledge and being able to assess the real serious consequences for the injured.

The aggravating feature for the offence in question is the death of the patient or other serious consequences. Under the Ukrainian Act on Emergency Medical Assistance, pharmaceutical staff members who, in emergency and other extreme situations, are required to provide the necessary medical assistance may also be the perpetrator of this offence (a pharmaceutical staff member is a person with pharmaceutical education, working in a pharmaceutical facility whose duties include wholesale trade in medicines, their storage, transport and/or retail sale of medicines for medical use, their manufacture, dispensing, storage and transport).

The provision of Article $139 \mathrm{CCU}$ may be in concurrence with other provisions of the Criminal Code of Ukraine. Establishing the legal qualification, it is necessary to differentiate the failure of a healthcare professional to provide aid to a patient (Article $139 \mathrm{CCU}$ ) from the factual states provided for in the dispositions of Article $135 \mathrm{CCU}$ ("Leaving a person in danger") and in the disposition of Article 136 CCU ("Failure to provide help to a person in a situation of endangered life").

According to V.M. Burdin, the provision provided for in Article $135 \mathrm{CCU}$ is of a special nature in relation to the provision of Article $139 \mathrm{CCU}$. The author justifies his view by the fact that Article $135 \mathrm{CCU}$ provides for criminal liability for leaving a person in life-threatening danger, and also by the fact that Article $139 \mathrm{CCU}$ does not indicate that the patient should be in a life-threatening condition. ${ }^{5} \mathrm{~A}$ different view is presented by V.Y. Yasenytskyy claiming that the actus reus of these offences is the same. He believes that the behaviour of the perpetrator (including a medical worker) who fails to provide help to another person fulfills the statutory features of Article $139 \mathrm{CCU} .{ }^{6}$ The issues of qualification of offences connected with medicine are closely related to the qualification of offences against life and health. ${ }^{7}$

5 V.M. Burdin, Osoblyvosti kryminalnoyi vidpovidalnosti likariv za nenadannya dopomohy khvoromu. Problemy derzhavotvorennya i zakhstu pravy lyudyny v Ukrayini, Lviv 2004, pp. 382-383.

6 V.Y. Yasenytskyy, Kvalifikatsiya zlochyniv, shcho posyahayut na prava patsiyenta, [in:] Aktualni problemy derzhavy i prava, eds. S.V. Kivalov, Yu.M. Oborotov, L.R. Bila, Odesa 2005, pp. 484-487.

7 Tema 1. Kvalifikatsiya zlochyniv proty zhyttya ta zdorova osoby, https://arm.naiau.kiev.ua/ books/kval-ok-zlochuniv-25-04-207/lectures/lecture_1.html [access: 20.09.2021]. 
The broadest and, at the same time, very imprecise norm is Article $140 \mathrm{CCU}$ ("Improper performance of professional duties by a medical or pharmaceutical professional"). The criminal liability for this offence takes place provided that there are serious consequences for the patient (death, suicide, causing serious injury to health, chronic illness). Serious consequences in this respect do not include consequences not affecting life and health, such as property damage and moral detriment, job losses, deterioration of social status. Although this approach is traditionally adopted in the practice and theory of criminal law in Ukraine, we disagree with it. In our opinion, if there is a causal link between the improper performance of professional duties by medical or pharmaceutical staff and the loss of employment or deterioration of social status, such consequences should be considered as fulfilling the statutory features of the offence.

In the legislation of Ukraine, there is no definition of the concept of professional duties of a pharmaceutical employee, at the same time in practice the term "pharmaceutical assistance" is used. According to some representatives of the doctrine, pharmaceutical assistance should be understood as a complex of behaviours involving the provision of medicinal products by pharmaceutical employees, as well as medical products that improve the quality of life and eliminate physical and mental suffering. ${ }^{8}$ The issues of the specificity of the activity of pharmaceutical workers are the subject of consideration of Y.V.Palytsya. ${ }^{9}$

It should be noted that the perpetrators of this offence may also be persons providing services in the field of plastic surgery and aesthetic dentistry. The improper performance of their duties may lead to irreversible consequences which may not directly cause serious injury to health but lead to a serious deterioration in the standard of living of the person concerned.

In the statutory features of this offence, the injured person is referred to as an "ill person" but it should be understood to mean the same as the term "patient". Anyone seeking medical help is a patient, but not necessarily an ill person. This approach is also supported by the concept of "patient's autonomy", which ensures, i.a., the right to the correct, high-quality and timely provision of medical and pharmaceutical services. Persons who, despite not having sought medical attention should be provided with medical assistance (e.g., a person who has lost consciousness as a result of an accident) should also be considered to be patients. Also pregnant women are not ill, but they are provided with medical care.

8 I.M. Fil, Farmatsevtychnyy pratsivnyk yak subyekt zlochynu, peredbachenoho st. 140 KK Ukrayiny, "Chasopys Kyyivskoho universytetu prava” 2013, no. 3, pp. 330-335.

9 Y.V. Palytsya, Tsikavi fakty z istoriyi likoznavstvo, https://nubip.edu.ua/sites/default/files/ u125/cikavi_fakti_z_istoriyi_likoznavstva.pdf [access: 10.11.2021]; eadem, Tsikavi fakty z istoriyi farmatsiyi, https://nubip.edu.ua/sites/default/files/u125/cikavi_fakti_z_istoriyi_farmaciyi.pdf [access: 10.11.2021]. 
The doctor is obliged to inform the patient of all the negative consequences of refusing the treatment. If, despite this, the patient still refuses treatment, an appropriate document is drawn up and the patient signs it in the presence of witnesses. Then the doctor is not responsible for the consequences, even if these are serious, or even led to the patient's death. At the same time, if the doctor does not explain the possibility of such consequences in the case of refusal, then his behaviour (in this case-omission), along with other statutory features met, should be qualified as failure to perform or improper performance of his/her duties.

The following actions (omissions) of medical and pharmaceutical staff should be qualified under Article $140 \mathrm{CCU}$ : delayed or incorrect diagnosis, leaving the patient without appropriate medical care, transfusion of blood of an incompatible group and other actions that may seriously deteriorate the patient's condition. Detailed analysis of the statutory features of this offence is presented by O.H. Berylo. ${ }^{10}$

The provision of para. 1 of Article $140 \mathrm{CCU}$ is of a blank character and general directives do not apply in this situation. In each individual case, it is necessary to analyze normative acts and protocols of the Ministry of Health of Ukraine, to indicate what principles are specifically violated, what medical regulations and protocol guidelines for specific medical activities have not been complied with. It is also necessary to take into account the individual characteristics of the injured person's body and to apply non-standard approaches in individual specific cases. In certain circumstances, the doctor may take a justified risk, and the possibility of force majeure should also be taken into account. For example, an ambulance arrived too late, but not because of the fault of the medical staff, but because of traffic jams, a lack of necessary medicines or an insufficient number of ambulances. In any case, it must be examined whether all possible measures have been properly used.

Sometimes, a severe consequence can result from the behaviour of a group of people performing their duties incorrectly. This includes, for example, a surgical procedure involving not only a doctor, but also an anaesthetist and a surgical nurse. As far as possible, it is necessary to determine the guilt and scope of socially harmful actions of each of the participants of such damage jointly inflicted.

The provision provided for in Article $140 \mathrm{CCU}$ - according to A.N. Yazukhin - has the character of a special norm in relation to the norms provided for in Article 119 CCU ("Unintentional murder") and Article 128 CCU ("Unintentional grave or medium bodily harm"). This author believes that manslaughter cannot be

${ }^{10}$ O.H. Berylo, Osoblyvosti rehulyuvannya suspilnykh vidnosyn shchodo vidpovidalnosti za nenadannya dopomohy khvoromu medychnym pratsivnykom u period Kyyivskoyi Rusi. Kryminolohichna teoriya ta praktyka: dosvid, problemy sohodennya ta shlyakhy yikh vyrishennya: materialy muzhvuz, Kyyiv 2017, pp. 11-14; idem, Kryminalna vidpovidalnist za nenadannya dopomohy khvoromu medychnym pratsivnykom, Kyyiv 2018 (dysertatsiya kandydata yurydychnykh nauk). 
charged against a surgeon who violated the rules of medical art during an operation or a doctor who made a wrong diagnosis, resulting in the death of a patient. ${ }^{11}$

The offence consisting of failure to provide or improper provision of medical assistance by a medical or pharmaceutical professional may be committed intentionally. If we exclude the possibility of attributing intentional action, we deal with a case in which a person could not and should not have foreseen the socially dangerous consequences of his or her behaviour. This can be an unexpected and unpredictable reaction of the body to a medicine administered, unusual properties of the patient's body, and therefore cases in which a socially dangerous effect would still occur, even if medical actions were performed on time and correctly. It should be noted that in this case we are talking about a lack of criminal liability, while other types of liability are not excluded.

Of particular interest (from the point of view of the subject matter of this study) is the norm contained in Article $141 \mathrm{CCU}$ ("Violation of the rights of the patient"). ${ }^{12}$ The specificity of this provision is that, with such a broad name, the actus reus of this offence covers only one act: conducting clinical trials of medicinal products without the consent of the patient or his legal representative. The criminal liability arises only in the event of the death of the patient or other serious consequences.

Clinical trials are carried out all over the world. It is now a traditional and necessary practice to improve treatment methods and find new and more effective medicines. There are international standards in this respect, such as: the Nuremberg Code of 1947: $;^{13}$ the Convention for the Protection of Human Rights and Dignity of the Human Being with regard to the Application of Biology and Medicine (often referred to as the Bioethical Convention), concluded in Oviedo on 4 April 1997;

11 A.N. Yazukhin, Spornyye voprosy kvalifikatsii prestupnykh deystviy meditsinskikh rabotnikov. Voprosy sovershenstvovaniya ugolovno-pravovogo regulirovaniya: mezhvuzov, Sb. Nauch. Tr. Sverdlovsk, 1988, pp. 101-105; K.A. Andriyovych, Nevirno postavlenyy diahnoz, vstanovlennya yakoho potyahlo za soboyu obrannya nepravylnoyi taktyky likuvannya, tyahne za soboyu kryminalnu vidpovidalnist (VS/KKS no. 127/16872/17 vid 02.10.2018), https://protocol.ua/ru/sud_nevirno_postavleniy [access: 20.09.2021]; N. Zozulya, Osoblyvosti prytyahnennya likariv do kryminalnoyi vidpovidalnosti, 2019, https://protocol.ua/ru/osoblivosti_prityagnennya_likariv_do_kriminalnoi_vidpovidalnosti [access: 20.09.2021].

12 The Criminal Code of Ukraine contains a provision in Article 131 ("Improper performance of professional duties resulting in infecting a person with HIV or other incurable infectious disease"), which is of special character in relation to the norm provided for in Article $141 \mathrm{CCU}$ ("Violation of the rights of the patient"). A special aggravating feature provided for in the provision (para. 2 of Article $131 \mathrm{CCU}$ ) is infecting two or more people. When legally classifying a specific act, Article 131 CCU must be applied, if the offender was a medical or pharmaceutical staff member.

13 The Nuremberg Code - a code of ethics formulated in 1947 by the International Military Tribunal, which set out 10 principles for the admissibility of human experimentation (including research into the effects of new drugs on the human body). The Code was created after a series of trials of doctors, Nazi criminals, tried in Nuremberg. See Nuremberg Code, https://en.wikipedia.org/ wiki/Nuremberg_Code [access: 20.09.2021]. 
Additional Protocol to the Convention on Human Rights and Biomedicine, concerning Biomedical Research (open for signature on 25 January 2005). ${ }^{14}$

Such experiments must be carried out on volunteers and only with their written consent. Although the title of Article 141 CCU uses the word "patient", it should apply to both ill and healthy people. Two problems arise related to this provision. If minors or disabled persons are involved in clinical trials, their legal representative must agree for them to participate. We believe, firstly, that it is generally inappropriate to involve minors and persons with disabilities in such trials. This can only be done in exceptional cases where these people are seriously ill and there is hope that a new drug will save their lives. It is about patient's autonomy, and the autonomy of minors and disabled patients is significantly reduced due to age and mental state. Secondly, the use of new medicines always entails a risk, so it should be assumed that criminal liability should arise not in the case of consequences: death or other serious consequences, but already in the case of the very undertaking of clinical trials of medicines without the patient's consent. The consequences can be remote in time and people need to take such risks with full awareness.

Article $142 \mathrm{CCU}$ ("Illegal experiments on human beings") practically reiterates the previous provision, which imposes criminal liability for conducting clinical trials without the written consent of the patient (Article $141 \mathrm{CCU}$ ). Paragraph 1 of Article $142 \mathrm{CCU}$ constructs the offence of causing danger. The liability is provided for the illegal conduct of medical-biological and psychological experiments on human being, if this poses a danger to his/her life and health. It should be noted that para. 2 of Article $142 \mathrm{CCU}$ also provides for an aggravated type of offence. These are situations where the injured person is a minor and where there are two or more injured persons. The aggravating feature is also the manner of conducting the illegal experiments: using coercion or deception, as well as the consequences: a long-term derangement of the injured person's health. In this case, the offender's attitude to the consequences must be characterised by involuntariness. There is no doubt that Article $142 \mathrm{CCU}$ does not provide for such consequences as the involuntary causing of death. In judicial practice and scholarly opinion, it is pointed out that the consequences constituting the statutory features mean only severe or moderate damage to health. On the other hand, in the case of the involuntary causing of the injured person's death, the act must be classified according to the general principles, namely under para. 2 of Article 142 and Article 119 CCU ("Involuntary causing of death").

There is no doubt that experiments are an integral part of progress in medicine; without them, it would not be possible to introduce new treatment technologies. The key issue is that, in accordance with the principle of patient's autonomy, the patient

${ }^{14}$ Council of Europe Treaty Series, no. 195, https://rm.coe.int/CoERMPublicCommonSearchServices/DisplayDCTMContent?documentId=090000168008371a [access: 20.09.2021]. 
himself has the right to dispose of his health, to receive complete, true, comprehensive information about the consequences of such experiments. Therefore, experiments on ill and healthy people carried out without their consent are considered illegal, the same is with any experiments carried out by unauthorized persons. Medical and biological experiments on human beings are also considered illegal if they do not meet the following conditions: they have no socially useful purpose; they are scientifically unjustified; they are not carried out in accredited medical institutions.

The individual's right to dispose of his or her organs and tissues is also a component of the patient's autonomy. The most often encountered phenomenon is donation. Donation takes place in accordance with the Act of Ukraine "On the donation of blood and its components" of 23 June 1995. ${ }^{15}$ Undoubtedly, donation is an honourable and socially beneficial phenomenon. Donation can only be voluntary. The collection of blood and/or its components from the donor is permitted only if the donor is not harmed.

The type of offence provided for in Article 144 CCU ("Forced donation") imposes criminal liability for such offences as: forced or insidious collection of blood from a person for the use for donation (para. 1 of Article $144 \mathrm{CCU}$ ). The law also provides for aggravated types in the case of acts committed against a minor, a helpless person or a person financially dependent on the offender (para. 2 of Article $144 \mathrm{CCU}$ ); and where the actions referred to in Article 144 paras. 1 or 2 were committed as part of previous agreement by a group of persons or for sale (para. 3 of Article $144 \mathrm{CCU}$ ).

This provision refers to the brutal way of committing an act (beatings, inflicting bodily injuries, threats), or deceiving the injured person - providing him/her with false information about the amount of blood that will be taken from them, the conditions for blood collecting, the purpose of its use, remuneration for donation. It is especially interesting to formulate the purpose of this offence. The provision of para. 1 of Article $144 \mathrm{CCU}$ has defined the purpose of it as "sing a person as a donor". It therefore means that the offences are committed with a direct intention of a specific purpose (dolus coloratus). This purpose means that the perpetrator intends to use this blood in the future for treatment, manufacture of medicines or research. Although it is an offence of generally-specified perpetrator, the offenders are usually medical personnel of specialized blood transfusion facilities and health care establishments.

One of the elements of the patient's autonomy is the right to dispose of their organs and tissues. Organ and tissue transplantation is a specific method of treatment involving the transplantation of an organ or other anatomical material taken from the donor.

15 Zakon Ukrayiny of 23 June 1995, no. 239/95-VR, Pro donorstvo krovi ta yiyi komponentiv, https://zakon.rada.gov.ua/laws/show/239/95-\%D0\%B2\%D1\%80\#Text [access: 20.09.2021]. 
The issue of organ and tissue transplantation is extremely broad and may be the subject of a separate scientific study. Ukraine's legislation on transplantations consists of the following legal acts: Law of Ukraine "On the use of transplantation of human anatomical materials" of 17 May 2018, no. 2427-VIII; ${ }^{16}$ Order of the Ministry of Health of Ukraine "On the determination of diagnostic criteria for brain death and the procedure for determining the time of human death" of 23 September 2013, no. $821 ;{ }^{17}$ Order of the Ministry of Health of Ukraine "On the approval of the form of medical documentation 'Reserve donor card' ${ }^{18}$ and instructions for filling it" of 22 August 2002, no. 323;19 decision of the Council of Ministers of Ukraine "On approval of the list of services and price lists in the field of tertiary (highly specialized) services related to medical care by organ and other anatomical materials transplantation provided by the participants of the pilot project to change the financial support mechanism for surgical treatment in transplantation of organs and other anatomical materials" of 18 December 2019, no. 1083;20 Order of the Ministry of Health of Ukraine "Conditions for ensuring the safety of anatomical materials during their transport" of 25 September 2000, no. $226 .{ }^{21}$ Research on the issues of transplantation was carried out by Ukrainian scientists. ${ }^{22}$

16 Zakon Ukrayiny of 17 May 2018, no. 2427-VIII, Pro zastosuvannya transplantatsiyi anatomichnykh materialiv lyudyni, https://zakon.rada.gov.ua/laws/show/2427-19\#Text [access: 20.09.2021].

${ }^{17}$ Nakaz Ministerstva okhorony zdorovya Ukrayiny of 23 September 2013, no. 821, Pro vstanovlennya diahnostychnykh kryteriyiv smerti mozku ta protsedury konstatatsiyi momentu smerti lyudyny, http://search.ligazakon.ua/1_doc2.nsf/link1/RE24289Z.html [access: 20.09.2021].

${ }_{18}$ A reserve donor is a donor who donates blood less than three times a year. A donor who donates blood three or more times a year is referred to as an active donor.

19 Nakaz Ministerstva okhorony zdorovya Ukrayiny of 22 July 2002, no. 323, Pro zatverdzhennya formy medychnoyi oblikovoyi dokumentatsiyi "Kartka donora rezervu" ta instruktsiyi shchodo yiyi zapovnennya, http://search.ligazakon.ua/1_doc2.nsf/link1/REG7019.html access: 20.09.2021].

${ }^{20}$ Postanovoyu Kabinetu Ministriv Ukrayiny of 18 December 2019, no. 1083, Pro zatverdzhennya pereliku posluh ta taryfiv na posluhy z nadannya tretynnoyi (vysokospetsializovanoyi) medychnoyi dopomohy metodom transplantatsiyi orhaniv ta inshykh anatomichnykh materialiv, yaki nadayutsya uchasnykamy pilotnoho proektu shchodo zminy mekhanizmu finansovoho zabezpechennya operatyvnoho likuvannya $\mathrm{z}$ transplantatsiyi orhaniv ta inshykh anatomichnykh materialiv, http://search. ligazakon.ua/1_doc2.nsf/link1/KP191083.html [access: 20.09.2021].

${ }^{21}$ Nakaz, Instruktsiya of 25 September 2000, no. 226, Pro zatverdzhennya normatyvno-pravovykh dokumentiv z pytan transplantatsiyi MOZ Ukrayiny, https://zakon.rada.gov.ua/laws/show/z069700\#Text [access: 20.09.2021].

${ }^{22}$ Y.O. Lisitsyna, Porushennya vstanovlenoho zakonom poryadku transplantatsiyi orhaniv abo tkanyn lyudyny ta nasylnytske donorstvo: kryminalno-pravova ta kryminolohichna kharakterystyka, Lviv 2016 (dysertatsiya na zdobuttya naukovoho stupenya kandydata yurydychnykh nauk), http:// dspace.lvduvs.edu.ua/bitstream/1234567890/466/1/lisitsina\%20dus.pdf [access: 10.11.2021]; H.V. Chebotarova, Kryminalno-pravovi problemy transplantatsiyi orhaniv abo tkanyn lyudyny ta donorstva krovi, Kyyiv 2003 (dysertatsiya kandydata yurydychnykh nauk); L.A. Zherzh, Kryminalno-pravova 
The reasons for committing this offence are socio-economic and socio-political in nature. This issue is analyzed in detail in the works of L.A. Zherzh and V.V. Rozmayita, ${ }^{23}$ as well as N.A. Zherzh, L.A. Zherzh and A.A. Melnychenko. ${ }^{24}$ These authors pay attention to social phenomena that cause illegal transplantation and illegal trade in human organs and tissues, such as a decrease in the standard of living and impoverishment of a large part of society. This is caused by unemployment, depreciation of the national currency, low wages and pensions, low earning capacity of the population against the background of high costs of medicines and medical services, especially in the field of transplantation. In practice, there is no adequate state funding in this area of medical services, there is also a significant difference in costs between the same treatments in different regions of the country. The presence of organized national and international crime in the field of transplantation deserves special attention. The issue of illegal transplantation and organ trafficking is dealt with by N. Bortnyk, G. Didkivska and V. Tylchyk..$^{25}$ They point out that a person deprived of resources in Ukraine, but knowing that he can become a potential donor, often decides to illegally sell his organs abroad. Such people look for offers on the Internet and go abroad under the guise of economic migrants. In this way, these people fall into the hands of illegal transplantologists who, under the guise of a medical examination for employment, remove their organs and tissues.

One of the negative phenomena related to the problems of transplantology, according to M. Radutskyy, is the poor level of development of medicine in Ukraine. ${ }^{26}$ He notes that in recent years transplantation procedures in Ukraine have not been carried out systematically. There are many reasons for this phenomenon: imperfect legislation, occurrence of various types of abuse, lack of regulatory and control mechanisms in this area. This has led to the fact that it is easier for the state to prohibit transplants than to control this process and ensure its financing. To meet the demand, patients have to be sent abroad. Budgetary funding, however, is only enough for few people, and the need is much greater. Most patients, having lost hope of government assistance, are forced to seek money on their own. For many

kharakterystyka ta zapobihannya shchlochynam, povyazanym z nezakonnoyu transplantatsiyeyu, Irpin 2021 (dysertatsiya na zdobuttya naukovoho stupenya doktor filosofiyi u haluzi prava), p. 304.

${ }^{23}$ L.A. Zherzh, V.V. Rozmayita, Determinanty koruptsiyi u diyalnosti medychnykh pratsivnykiv. Fiskalna polityka: teoretychni ta praktychni aspekty yurydychnoyi nauky: zb. tez, Irpin 2018, pp. 59-62.

${ }^{24}$ N.A. Zherzh, L.A. Zherzh, A.O. Melnychenko, Zapobihannya vchynennyu zlochyniv u sferi torhivli lyudmy $v$ Ukrayini. Kryminolohichna teoriya i praktyka: dosvid, problemy sohodennya ta shlyakhy yikh vyrishennya, Kyyiv 2017, pp. 137-141.

${ }^{25}$ N. Bortnyk, G. Didkivska, V. Tylchyk, The impact of international labour migration on the development of states under globalization: economic and legal aspects, "Baltic Journal of Economic Studies" 2018, vol. 4(2), pp. 47-52.

${ }^{26}$ M. Radutskyy, Transplantatsiya: yak vylikuvaty ukrayinskykh patsiyentiv ta pochaty zaroblyaty na inozemtsyakh, 2020, https://life.pravda.com.ua/columns/2020/06/4/241214 [access: 10.06.2021]. 
families, such operations are financially inaccessible even in Ukraine, which gives rise to illegal transplantation.

Concerning the statutory features of the offence described in Article $143 \mathrm{CCU}$ ("Violation of the statutory procedure for transplanting human organs or tissues"), this provision has a rather complex structure and contains different but mutually related sets of statutory features of the offence: the infringement of the transplantation procedure; illegal trade in human organs or tissues; participation in supranational organisations that carry out such activities. With the exception of the latter, all these offences have aggravated types. The provision of para. 1 of Article 143 CCU reiterates in fact the title of the article and we do not find any explanation of the features of the offence contained therein.

Transplantation is considered illegal, i.e. carried out in violation of the procedure provided for by law, where: there is no written consent from a duly informed donor (this condition is optional in urgent cases where there is a real threat to the life of the recipient); there is no justified request from the medical case conference that the patient cannot be helped in any other manner; the harm to the donor is greater than that threatening the recipient; the organs and tissues taken are not allowed for transplantation by the Ministry of Health of Ukraine; the transplantation is carried out in a medical or scientific establishment which is not authorised to perform such procedures. It is forbidden to take organs from minors, disabled people, mentally ill people, prison inmates, people with diseases that can be transmitted to the recipient, people who were donors if an organ other than an even organ or part of an organ or tissue that does not regenerate is taken from a living donor; organs have been taken from a deceased person who did not consent to this before his or her death.

Any type of transplantation which infringes the relevant provisions should be considered illegal (for example, carrying out transplantation without compliance with the applicable procedure, without the consent of the living donor or his legal representatives, disfiguring the body of a deceased donor when removing anatomical materials).

Paragraph 2 of Article 144 CCU provides for an aggravated type of this offence. The aggravating feature is deceiving and forcing the donor to consent to the removal of organs and tissues. Paragraph 3 of Article $144 \mathrm{CCU}$ provides for further aggravating features (including the individual characteristics of the donor). The victims, in this case, may be people who are in a state of helplessness (understood as a state which deprives the victim of the possibility of taking care of themselves and making the right decision, e.g. disabled people, elderly people, pregnant women, traumatised people. Other types of states of helplessness are those in which a person is unable to recover from a situation in which he/she found himself/herself or is in financial or other dependence on the offender.

Paragraph 3 of Article 143 CCU provides for the criminal liability for illegal trade in human organs or tissues. This means concluding contracts which provide 
for their purchase and sale. Such contracts also include foreign contracts. According to Ukrainian legislation, such contracts are considered illegal in any case, except for cases of buying and selling bone marrow.

As mentioned above, this is a separate criminal situation. Therefore, if someone has illegally taken human organs and tissues through deception or coercion, it is possible to qualify this act under paras. 2 and 4 of Article $143 \mathrm{CCU}$.

Paragraph 5 of Article $143 \mathrm{CCU}$ provides for an aggravated type, whose aggravating feature is the commission of the offence defined in paras. 2, 3 or 4 of Article 143 after prior agreement by a group of persons, or participation in supranational organisations involved in such activities. These transnational organisations (in the context of Article $143 \mathrm{CCU}$ ) include organisations that systematically engage in the removal of organs and/or tissues for transplantation from human beings, by deception or coercion, or illegal international trade in organs of living or deceased persons.

The offender under Article $143 \mathrm{CCU}$ ("Violation of the statutory procedure for transplanting human organs or tissues") may be of general or individual character. It depends on the type of offence committed under this provision. It may also be a medical professional who has the right to perform a transplantation but violates its procedure, sells organs or tissues, participates in transnational organizations.

Scholars indicate that the so-called dark number of offences under Article 143 $\mathrm{CCU}$ is high. This is confirmed by the research of O.V. Illyashenko, who conducted a survey among doctors, which showed that the ratio of reported to unreported offences related to illegal transplants is $1: 5 .{ }^{27}$

An offence that grossly violates the principle of patient's autonomy and which can only be committed by individuals of specific characteristics (specific-offender offence) and which can be attributed primarily to medical staff members is the disclosure of medical privacy (Article $145 \mathrm{CCU}$ "Illegal disclosure of medical privacy"). Medical privacy covers information about the facts of seeking psychiatric help and treatment in a psychiatric clinic, as well as other information about the health of a given person; data of an intimate nature, concerning tests and surgical treatment or procedures performed in medical facilities. A distinction should be made between medical privacy (information on the patient) and medical secrets (information for the patient). It is the medical secret that is an unconditional element of the patient's autonomy. This is information that the doctor must provide to the patient.

When it comes to medical privacy, the circle of people to whom the information covered by it may be legally known is quite broad: these are medical staff, lawyers,

${ }^{27}$ O.V. Illyashenko, Zapobihannya nezakonniy torhivli orhanamy i tkanynamy lyudyny v Ukrayini ta inshykh Yevropeyskykh krayinakh (porivnyalno-pravove doslidzhennya), Kyyiv 2008 (avtoref. dys. na zdobuttya nauk. stupenya kand. yuryd. nauk), p. 21. 
law enforcement officials, notaries, educators, teachers. Everyone has the right to the protection of their personal life secrets, including medical privacy. For the disclosure of such data, liability is possible under Article $182 \mathrm{CCU}$ ("Infringement of the inviolability of private life").

Also, in accordance with the Civil Code of Ukraine, everyone has the right to keep confidential information about their health status, medical assistance, diagnosis and statements obtained during medical examinations. It is forbidden to provide information about the diagnosis and treatment methods for a given person at the place of their work or study.

\section{CONCLUSIONS}

The effectiveness of criminal law in general and of its individual institutions (e.g., criminal liability of medical staff) is directly related to the functioning of criminal policy. This policy is based on the efficiency of criminal law and depends on the effectiveness of criminal law and institutions.

We analyzed the issues of criminal liability of medical staff members. Although there is no separate chapter in the Criminal Code of Ukraine devoted exclusively to offences committed by healthcare personnel, nevertheless - as indicated above a significant number of them are included in this Code. Table 1 presents the medical offences statistics for 2019 using four categories of indicators.

Table 1. Medical offences statistics for 2019

\begin{tabular}{|c|c|c|c|c|c|}
\hline No. & Article of the CCU & 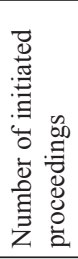 & 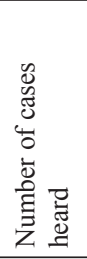 & 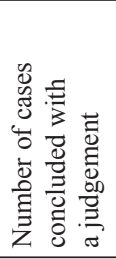 & 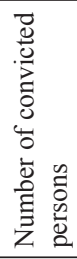 \\
\hline 1 & $\begin{array}{l}130 \text { ("Infecting with HIV or other incurable infectious } \\
\text { disease") }\end{array}$ & 0 & 0 & 0 & 0 \\
\hline 2 & $\begin{array}{l}131 \text { ("Improper performance of professional duties } \\
\text { resulting in infecting a person with HIV or other incur- } \\
\text { able infectious disease") }\end{array}$ & 0 & 0 & 0 & 0 \\
\hline 3 & $\begin{array}{l}132 \text { ("Disclosure of information on the conduct of } \\
\text { medical examinations for the detection of human } \\
\text { infection with HIV or other incurable infectious } \\
\text { disease") }\end{array}$ & 0 & 0 & 0 & 0 \\
\hline 4 & 134 ("Illegal abortion or sterilisation") & 0 & 0 & 0 & 0 \\
\hline 5 & 135 ("Leaving a person in danger") & 8 & 1 & 1 & 2 \\
\hline 6 & $\begin{array}{l}136 \text { ("Failure to provide help to a person in a situation } \\
\text { of endangered life") }\end{array}$ & 0 & 0 & 0 & 0 \\
\hline 7 & 138 ("Illegal medical activity") & 0 & 0 & 0 & 0 \\
\hline
\end{tabular}




\begin{tabular}{|c|c|c|c|c|c|}
\hline No. & Article of the $\mathrm{CCU}$ & 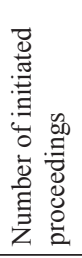 & 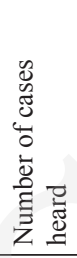 & 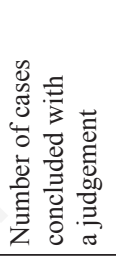 & 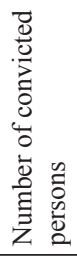 \\
\hline 8 & $\begin{array}{l}139 \text { ("Failure to provide aid to the patient by a health- } \\
\text { care professional") }\end{array}$ & 0 & 0 & 0 & 0 \\
\hline 9 & $\begin{array}{l}140 \text { ("Improper performance of professional duties by } \\
\text { a medical or pharmaceutical professional") }\end{array}$ & 6 & 3 & 0 & 0 \\
\hline 10 & 141 ("Violation of the rights of the patient") & 0 & 0 & 0 & 0 \\
\hline 11 & 142 ("Illegal experiments on human beings") & 0 & 0 & 0 & 0 \\
\hline 12 & $\begin{array}{l}143 \text { ("Violation of the statutory procedure for trans- } \\
\text { planting human anatomical material") }\end{array}$ & 1 & 0 & 0 & 0 \\
\hline 13 & 144 ("Forced donation") & 0 & 0 & 0 & 0 \\
\hline 14 & $\begin{array}{l}145 \text { ("Unlawful disclosure of information covered by } \\
\text { medical privacy") }\end{array}$ & 0 & 0 & 0 & 0 \\
\hline
\end{tabular}

Source: Office of the Attorney General, www.gp.gov.ua/ua/index.html [access: 20.09.2021].

As it can be noticed, these are very few cases, and convictions are rare..$^{28}$ According to the All-Ukrainian Council for the Protection of Patients' Rights and Safety, only $10-15 \%$ of people report to the authorities cases of offences committed by health care professionals. ${ }^{29}$ Medical offences are traditionally classified as covert crimes. In the legal literature, a quite successful attempt was made to explain the reluctance of victims to request law enforcement to protect their health rights. ${ }^{30}$

Factors that determine the non-disclosure of offences related to patient's autonomy include: reluctance to disclose information about the occurrence of the disease; inefficient work of law enforcement authorities (even if proceedings are initiated, it can be proceeded for months or even years, so the injured persons report their cases to law enforcement only exceptionally, e.g., where there are serious health or life consequences); a certain "clan" nature of the medical circles, a kind of solidarity among doctors, which makes patients feel that the truth cannot be revealed; the doctor-patient conflict often ends so that the doctor, wanting to

${ }^{28}$ The accuracy of the decisions made by the courts is sometimes questionable. See K.A. Andriyovych, $500000 \mathrm{hrn}$. za invalidnist dytyny vnaslidok nedbalosti likariv Verkhovnyy sud vyznav dostatnim vidshkoduvannyam (VS/KTSS no. 520/16987/15-ts vid 04.09.2019), https://protocol.ua/ru/ vs_ktss_500_000_grn [access: 20.09.2021].

${ }_{29}$ Pochemu vrachi ne otvechayut za svoi oshibki?, http://paralleli.if.ua/news/5500.html [access: 10.06.2021].

${ }^{30}$ V. Plotnikova, Faktory latentizatsii prestupleniy v sfere meditsinskoy deyatelnosti, "Vestnik Natsionalnoy akademii prokuratury Ukrainy" 2011, no. 2, pp. 101-106; Y.O. Shopina, Criminal liability of a medical or pharmaceutical worker for an offense connected with performance of professional duties, Kyiv 2020 (abstract of candidate thesis in legal sciences), pp. 12-24. 
avoid negative consequences for his reputation, simply prefers to pay the patient an informal compensation (without initiating any proceedings).

As there is no systematisation of norms for the criminal liability of medical professionals in Ukrainian legislation, we have taken such bioethical phenomenon as patient's autonomy as the basis of our research, which has narrowed the scope of the norms under the study. All the criminal law norms analyzed provide for criminal liability for an attack on legal relationships arising on the basis of the patient's autonomy, in this case arising from a doctor-patient relationship. On the one hand, the subject of these relationships is a patient who has a number of rights and must have full state-guaranteed access to them. On the other hand, the subject of these legal relationships is a medical professional who is obliged to provide the patient with high-quality medical services.

As a rule, the liability of doctors in case law is traditionally linked to the concept of medical error (medical art error). Such liability is usually perceived through the presence or lack of guilt in the actions of a particular person, in this context: a medical professional. Generally, the criminal liability of healthcare professionals covers two offences, which are described in Article $140 \mathrm{CCU}$ ("Improper performance of professional duties by a medical or pharmaceutical professional") and Article 139 CCU ("Failure to provide aid to the patient by a healthcare professional").

We have analyzed not only these two provisions, but also a number of other offences, which concern not only legal relationships arising in the course of the performance (or non-performance/improper performance) of professional duties by medical professionals, but also provisions which cover legal relationships arising out of the implementation of the principle of patient's autonomy. It should be noted that studying only the criminal aspect of the infringement of patient's autonomy is not sufficient to determine whether that autonomy is fully respected as part of the state's legal policy.

From the point of view of the science of criminal law, it is necessary to consider the term "patient" (in the broad sense of the word, as used herein) and it should be perceived both as the injured person (in procedural terms) and as a victim of certain violations of the patient's autonomy, the consequences of which go beyond the sphere of criminal law. Thus, if we take into account the socio-political component together with the criminal and legal factor, this will allow us to draw a conclusion about the phenomenon of absolute victimization of the patient in Ukraine. ${ }^{31}$ Of course, only part of the conduct related to the violation of the patient's autonomy is governed by criminal law and can be considered a criminal offence.

31 S. Dutchak, Fenomen absolyutnoy viktimnosti patsiyenta v Ukraine, "Legea si viata" 2017 (April), pp. 36-40. 


\section{REFERENCES}

\section{Literature}

Berylo O.H., Kryminalna vidpovidalnist za nenadannya dopomohy khvoromu medychnym pratsivnykom, Kyyiv 2018 (dysertatsiya kandydata yurydychnykh nauk).

Berylo O.H., Osoblyvosti rehulyuvannya suspilnykh vidnosyn shchodo vidpovidalnosti za nenadannya dopomohy khvoromu medychnym pratsivnykom u period Kyyivskoyi Rusi. Kryminolohichna teoriya ta praktyka: dosvid, problemy sohodennya ta shlyakhy yikh vyrishennya: materialy muzhvuz, Kyyiv 2017.

Bortnyk N., Didkivska G., Tylchyk V., The impact of international labour migration on the development of states under globalization: economic and legal aspects, "Baltic Journal of Economic Studies" 2018, vol. 4(2), DOI: https://doi.org/10.30525/2256-0742/2018-4-2-47-52.

Burdin V.M., Osoblyvosti kryminalnoyi vidpovidalnosti likariv za nenadannya dopomohy khvoromu. Problemy derzhavotvorennya i zakhstu pravy lyudyny v Ukrayini, Lviv 2004.

Chebotarova H.V., Kryminalno-pravovi problemy transplantatsiyi orhaniv abo tkanyn lyudyny ta donorstva krovi, Kyyiv 2003 (dysertatsiya kandydata yurydychnykh nauk).

Dutchak S., Fenomen absolyutnoy viktimnosti patsiyenta v Ukraine, "Legea si viata" 2017 (April).

Fil I.M., Farmatsevtychnyy pratsivnyk yak subyekt zlochynu, peredbachenoho st. 140 KK Ukrayiny, "Chasopys Kyyivskoho universytetu prava" 2013, no. 3.

Illyashenko O.V., Zapobihannya nezakonniy torhivli orhanamy i tkanynamy lyudyny $v$ Ukrayini ta inshykh Yevropeyskykh krayinakh (porivnyalno-pravove doslidzhennya), Kyyiv 2008 (avtoref. dys. na zdobuttya nauk. stupenya kand. yuryd. nauk).

Likhova S., Mozgawa M., Criminal Law Protection of the Autonomy of Patients in Ukraine. Part 1, "Studia Iuridica Lublinensia" 2021, vol. 30(4),

DOI: http://dx.doi.org/10.17951/sil.2021.30.4.373-391.

Plotnikova V., Faktory latentizatsii prestupleniy v sfere meditsinskoy deyatelnosti, "Vestnik Natsionalnoy akademii prokuratury Ukrainy" 2011, no. 2.

Shopina Y.O., Criminal liability of a medical or pharmaceutical worker for an offense connected with performance of professional duties, Kyiv 2020 (abstract of candidate thesis in legal sciences).

Shopina Y.O., Kryminalna vidpovidalnist medychnoho abo farmatsevtychnoho pratsivnyka za vchynennya zlochynu, povyazanoho z vykonannyam profesiynykh obovyazkiv, Kyyiv 2020 (dysertatsiya kandydata yurydychnykh nauk).

Yasenytskyy V.Y., Kvalifikatsiya zlochyniv, shcho posyahayut na prava patsiyenta, [in:] Aktualni problemy derzhavy i prava, eds. S.V. Kivalov, Yu.M. Oborotov, L.R. Bila, Odesa 2005.

Yazukhin A.N., Spornyye voprosy kvalifikatsii prestupnykh deystviy meditsinskikh rabotnikov. Voprosy sovershenstvovaniya ugolovno-pravovogo regulirovaniya: mezhvuzov, Sb. Nauch. Tr. Sverdlovsk, 1988.

Zherzh L.A., Kryminalno-pravova kharakterystyka ta zapobihannya shchlochynam, povyazanym z nezakonnoyu transplantatsiyeyu, Irpin 2021 (dysertatsiya na zdobuttya naukovoho stupenya doktor filosofiyi u haluzi prava).

Zherzh L.A., Rozmayita V.V., Determinanty koruptsiyi u diyalnosti medychnykh pratsivnykiv. Fiskalna polityka: teoretychni ta praktychni aspekty yurydychnoyi nauky: zb. tez, Irpin 2018.

Zherzh N.A., Zherzh L.A., Melnychenko A.O., Zapobihannya vchynennyu zlochyniv u sferi torhivli lyudmy v Ukrayini. Kryminolohichna teoriya i praktyka: dosvid, problemy sohodennya ta shlyakhy yikh vyrishennya, Kyyiv 2017. 


\section{Online sources}

Additional Protocol to the Convention on Human Rights and Biomedicine, concerning Biomedical Research, Strasbourg, 25.01.2005, Council of Europe Treaty Series, no. 195, https://rm.coe.int/CoERMPublicCommonSearchServices/DisplayDCTMContent?documentId=090000168008371a [access: 20.09.2021].

Andriyovych K.A., 500000 hrn. za invalidnist dytyny vnaslidok nedbalosti likariv Verkhovnyy sud vyznav dostatnim vidshkoduvannyam (VS/KTSS no. 520/16987/15-ts vid 04.09.2019), https:// protocol.ua/ru/vs_ktss_500_000_grn [access: 20.09.2021].

Andriyovych K.A., Nevirno postavlenyy diahnoz, vstanovlennya yakoho potyahlo za soboyu obrannya nepravylnoyi taktyky likuvannya, tyahne za soboyu kryminalnu vidpovidalnist (VS/KKS no. 127/16872/17 vid 02.10.2018), https://protocol.ua/ru/sud_nevirno_postavleniy [access: 20.09.2021].

Lisitsyna Y.O., Porushennya vstanovlenoho zakonom poryadku transplantatsiyi orhaniv abo tkanyn lyudyny ta nasylnytske donorstvo: kryminalno-pravova ta kryminolohichna kharakterystyka, Lviv 2016 (dysertatsiya na zdobuttya naukovoho stupenya kandydata yurydychnykh nauk), http:// dspace.lvduvs.edu.ua/bitstream/1234567890/466/1/lisitsina\%20dus.pdf [access: 10.11.2021].

Nuremberg Code, https://en.wikipedia.org/wiki/Nuremberg_Code [access: 20.09.2021].

Office of the Attorney General, www.gp.gov.ua/ua/1stat [access: 20.09.2021].

Office of the Attorney General, www.gp.gov.ua/ua/index.html [access: 20.09.2021].

Osoblyvosti prytyahnennya likariv do kryminalnoyi vidpovidalnosti, 2019, https://protocol.ua/ru/ osoblivosti_prityagnennya_likariv_do_kriminalnoi_vidpovidalnosti [access: 20.09.2021].

Palytsya Y.V., Tsikavi fakty z istoriyi farmatsiyi, https://nubip.edu.ua/sites/default/files/u125/cikavi_fakti_z_istoriyi_farmaciyi.pdf [access: 10.11.2021].

Palytsya Y.V., Tsikavi fakty z istoriyi likoznavstvo, https://nubip.edu.ua/sites/default/files/u125/cikavi_fakti_z_istoriyi_likoznavstva.pdf [access: 10.11.2021].

Pochemu vrachi ne otvechayut za svoi oshibki?, http://paralleli.if.ua/news/5500.html [access: 10.06.2021].

Radutskyy M., Transplantatsiya: yak vylikuvaty ukrayinskykh patsiyentiv ta pochaty zaroblyaty na inozemtsyakh, 2020, https://life.pravda.com.ua/columns/2020/06/4/241214 [access: 10.06.2021].

Tema 1. Kvalifikatsiya zlochyniv proty zhyttya ta zdorova osoby, https://arm.naiau.kiev.ua/books/ kval-ok-zlochuniv-25-04-207/lectures/lecture 1.html [access: 20.09.2021].

Zozulya N., Osoblyvosti prytyahnennya likariv do kryminalnoyi vidpovidalnosti, 2019, https://protocol. ua/ru/osoblivosti_prityagnennya_likariv_do_kriminalnoi_vidpovidalnosti [access: 10.11.2021].

\section{Legal acts}

Nakaz, Instruktsiya of 25 September 2000, no. 226, Pro zatverdzhennya normatyvno-pravovykh dokumentiv z pytan transplantatsiyi MOZ Ukrayiny.

Nakaz Ministerstva okhorony zdorovya Ukrayiny of 22 July 2002, no. 323, Pro zatverdzhennya formy medychnoyi oblikovoyi dokumentatsiyi "Kartka donora rezervu" ta instruktsiyi shchodo yiyi zapovnennya.

Nakaz Ministerstva okhorony zdorovya Ukrayiny of 23 September 2013, no. 821, Pro vstanovlennya diahnostychnykh kryteriyiv smerti mozku ta protsedury konstatatsiyi momentu smerti lyudyny.

Postanovoyu Kabinetu Ministriv Ukrayiny of 18 December 2019, no. 1083, Pro zatverdzhennya pereliku posluh ta taryfiv na posluhy z nadannya tretynnoyi (vysokospetsializovanoyi) medychnoyi dopomohy metodom transplantatsiyi orhaniv ta inshykh anatomichnykh materialiv, yaki 
nadayutsya uchasnykamy pilotnoho proektu shchodo zminy mekhanizmu finansovoho zabezpechennya operatyvnoho likuvannya $\mathrm{z}$ transplantatsiyi orhaniv ta inshykh anatomichnykh materialiv. Zakon Ukrayiny of 23 June 1995, no. 239/95-VR, Pro donorstvo krovi ta yiyi komponentiv.

Zakon Ukrayiny of 5 July 2012, no. 5081-VI, Pro ekstrenu medychnu dopomohu.

Zakon Ukrayiny of 17 May 2018, no. 2427-VIII, Pro zastosuvannya transplantatsiyi anatomichnykh materialiv lyudyni.

\begin{abstract}
ABSTRAKT
Celem artykułu jest analiza zjawiska ,autonomii pacjenta” jako przedmiotu ochrony prawnokarnej. Artykuł został podzielony na dwie części. W tej części uwagę skupiono na omówieniu możliwych podstaw odpowiedzialności karnej w przypadku naruszenia autonomii pacjenta. Należy podkreślić, że oczywiście tylko część zachowań naruszających dobro prawne, jakim jest autonomia pacjenta, jest regulowana przez prawo karne, a zatem może skutkować odpowiedzialnością karną. Autorzy dokonują analizy przestępstw, których popełnienie przez personel medyczny może naruszać autonomię pacjenta. Dodatkowo przedstawiają statystyki dotyczące liczby przestępstw medycznych obejmujące rok 2019.
\end{abstract}

Słowa kluczowe: autonomia pacjenta; odpowiedzialność karna; przestępstwa; personel medyczny; ochrona prawnokarna 